\title{
Pengaruh Live Performance, Kualitas Pelayanan, dan Persepsi Harga terhadap Kepuasan Penonton Sendratari Ramayana Prambanan
}

\author{
Elvira \\ Program Pascasarjana Institut Seni Indonesia Yogyakarta \\ elviradjimat10@gmail.com
}

\begin{abstract}
Abstrak
Penelitian ini bertujuan untuk mengetahui pengaruh live performance, kualitas layanan, dan persepsi harga terhadap kepuasan khalayak Sendratari Ramayana Prambanan. Penelitian dilakukan di Teater dan Pertunjukan Panggung Sendratari Ramayana Prambanan, kawasan wisata Candi Prambanan, Kota Yogyakarta dengan sampel mengumpulkan sebanyak 100 responden di panggung tertutup Gedung Tri Murti dan panggung terbuka Ramayana Prambanan. Teknik pengambilan sampel dilakukan dengan metode survei menggunakan kuesioner dengan teknik accidental sampling. Metode analisis menggunakan analisis regresi berganda dan bertahap pada Uji Sampel Uji Independen T-Test. Hasil penelitian regresi pada panggung tertutup secara statistik menunjukkan nilai F0 sebanyak 23.136 dan panggung terbuka menunjukkan F0 sebanyak 14.400 dengan Fsig $=0,000<0,05$. Analisis regresi pada variabel X1, X2 snf X3 berpengaruh secara signifikan. Uji T Uji Sampel Independen menunjukkan bahwa terdapat pengaruh yang signifikan terhadap panggung tertutup dengan nilai rerata 25.700 dan 23.9500 pada tahap terbuka dengan tingkat signifikansi 0,025 kurang dari $5 \%(0,025<0,050)$ yang menunjukkan ada perbedaan antara kepuasan penonton pada tahap yang dekat dan terbuka.
\end{abstract}

Kata kunci: perfasio hidup, kualitas pelayanan, persepsi harga, kepuasan penonton, sendratari ramayana prambanan

\begin{abstract}
This study aims to determine the effect of live performance, service quality, and price perceptions of the audience satisfaction Ramayana Prambanan Ballet. The study was conducted at the Theater and Performances of Ramayana Prambanan, Prambanan Temple, Yogyakarta with a sample of 100 respondents on the closed stage of Tri Murti Building and Ramayana Prambanan open stage. The sampling technique was conducted by survey method using questionnaires with accidental sampling technique. The analytical method used multiple regression analysis and stepwise on the Independent Test Sample Test T-Test. The result of regression research on closed stage statistically shows $F 0$ value as much as 23.136 and open stage shows F0 14,400 with Fsig =0,000<0,05. Regression analysis on variables $X 1, X 2$ snf X3 have significant effect. The Independent Sample T-Test shows that there is a significant effect on the closed stage with a mean value of 25,700 and 23,9500 in the open stage with a 0.025 significance level of less than $5 \%(0.025<0.050)$ which indicates there is a difference between audience satisfaction in the near and open stage.
\end{abstract}

Keywords: live performance, service quality, price perceptions, audience's satisfaction, sendratari ramayana prambanan 


\section{Pendahuluan}

Yogyakarta memiliki potensi budaya yang menunjang pembangunan pariwisata dan kesenian. Penampilan seni dan budaya di samping menarik perhatian wisatawan juga meningkatkan sumber daya bagi masyarakat. Daya tarik tersebut menjadikan seni pertunjukkan di Yogyakarta semakin menunjukan eksistensinya di dunia kesenian dan mampu bersaing di kelasnya. Kesenian itu ialah Sendratari Ramaya Prambanan yang rutin melakukan pementasan sejak tahun 1961, cerita diangkat dari kisah Rama dan Sita dipertunjukkan di dekat Candi Prambanan di Yogyakarta.

Kisah Ramayana sebagai cerita pahlawan atau wiracarita Ramayana dikemas untuk membawakan sebuah cerita yang terkenal dalam pewayangan di Indonesia. Sendratari ini juga mengutamakan gerak-gerik dan ekspresi sebagai pengganti dialog, sehingga dapat menyampaikan komunikasi yang mudah dipahami oleh penonton dikalangan perbedaan budaya dan bahasa.

Pertunjukan Sendratari Ramayana Prambanan ini terletak cukup jauh dari pusat kota Yogyakarta, namun dengan keistimewaan berlatar belakang Candi Prambanan dibangun menyatu dengan lingkungan alam serta dekorasi-dekorasi yang menyatu dengan alam, pertunjukan Sendratari Ramayana Prambanan ini memiliki daya tariknya tersendiri di kalangan wisatawan domestik dan internasional serta pertunjukan ini semakin meningkat daya jualnya baik dari tiket pertunjukan di kalangan kelas menengah ke atas dan kalangan kelas menengah ke bawah, untuk menonton pertunjukan Sendratari Ramayana Prambanan.

Panggung terbuka (outdoor) pertunjukan Sendratari Ramayana Prambanan, yang memiliki kapasitas 991 penonton ini, memiliki letak strategis di sebelah barat Candi Prambanan, dan penonton menghadap ke timur. Salah satu daya tarik panggung terbuka ini ialah penonton melihat ketiga candi utama yaitu Candi Siwa, Candi Wisnu, dan Candi Brahma. Dipentaskan pada malam hari dengan pencahayaan yang kuat untuk memberi efek latar yang megah dan atraktif. Keunikan dari panggung terbuka ini, diselenggarakan hanya pada musim kemarau berkisar bulan Mei-Oktober bergantung pada kondisi cuaca dan dalam penyajian ceritanya pada panggung terbuka menawarkan empat episode: (1) Hilangnya Sita; (2) Hanuman Duta; (3) Gugurnya Kumbakarna; (4) Api Suci Sita.

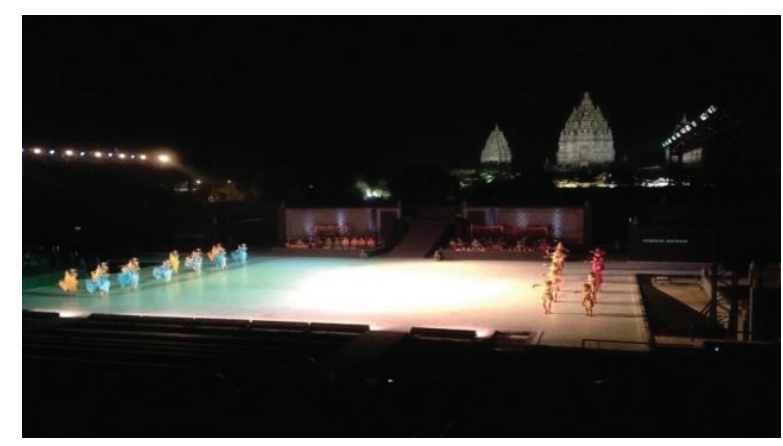

Gambar 1. Pertunjukan panggung terbuka Prambanan (Elvira, Mei 2017)

Panggung tertutup (indoor) pertunjukan Sendratari Ramayana Prambanan, memiliki kapasitas sebanyak 400 penonton. Di Gedung Trimurti dalam format cerita penuh atau tidak 
berepisode seperti panggung terbuka, panggung tertutup pentas pada bulan November-April dalam setahunnya. Adapun kelebihan dari panggung tertutup terbebas dari kondisi cuaca yang tidak mendukung. Penonton pun bisa lebih jelas melihat penampilan pemain dan melihat lebih jelas ekspresi tokoh dalan peran Sendratari Ramayana Prambanan.

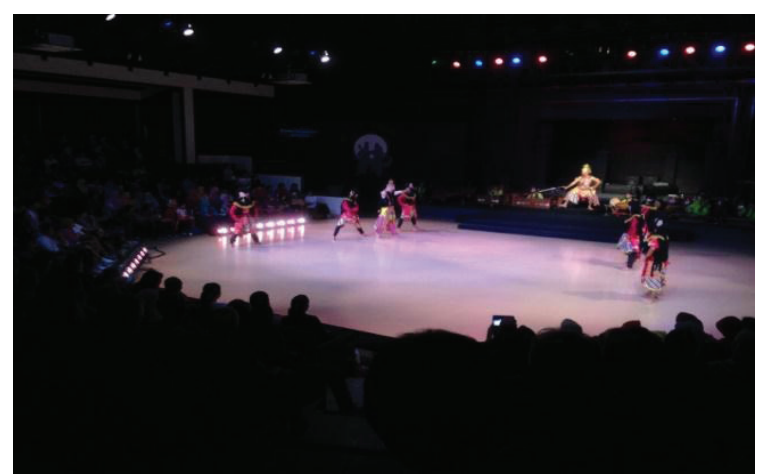

Gambar 2. Pertunjukan panggung tertutup Trimurti (Elvira, Februari 2017)

Dalam menyajikan seni live performance yang berkualitas menjadi salah satu upaya pemenuhan kebutuhan untuk penonton. Pertunjukan yang berkualitas dengan harapan penonton mengalami sesuatu yang tidak biasa dengan apa yang dilihat secara langsung (live) dari tampilan panggung dan atraksi penari. Dalam pelayanan di Ramayana Prambanan pun memiliki kekurangannya dalam melayani penonton yang menyaksikan pertunjukan sampai selesai, kurangnya rasa peduli kepada penonton yang terlampau banyak dan bagaimana pelayanan di Ramayana Prambanan bisa membuat penonton merasa terlayani dengan baik sampai pertunjukan selesai. Adapun harga tiketnya cukup menarik di tahun 2016 dan 2017. Harga tiket tahun 2016 mulai dari Rp. 125.000,- s.d. Rp. 375.000,-, akan mengalami kenaikan harga di tahun 2017 mulai dari Rp. 125,000,- s.d. Rp. 400.000,-. Harga tiket yang ditawarkan pada pertunjukan Sendratari Ramayana Prambanan memiliki harga yang cukup mahal namun pertunjukan ini tidak pernah sepi akan pengunjung.

Tingkat kepuasan penonton menjadi ukuran keberhasilan pertunjukan Sendratari Ramayana Prambanan. Semakin baik pengelolaan Ramayana Prambanan semakin puas penonton yang menyaksikan Sendratari Ramayana Prambanan. Kepuasan penonton ini diperoleh dari berbagai aspek perilaku konsumen yang ditampilkan sesuai harapan yang didapatkan oleh penonton. Secara garis besar penelitian ini mewujudkan hasil dari pengaruh live performance, kualitas pelayanan dan persepsi harga terhadap kepuasan penonton menjadi variabel yang terkait bagi perkembangan pengelolaan pertunjukan. Hal tersebut akan diketahui penonton saat menyaksikan dan menilai pertunjukan Sendratari Ramayana Prambanan. 


\section{Kajian Pustaka}

\section{A. Live Performance}

Pertunjukan langsung (live performance) tetap memberikan berbagai hiburan yang konsisten menarik dimata masyarakat. Menurut Minor, Brewerton dan Angela (2004) ada lima dimensi service setting-nya sebuah live performance, baik dalam teater, musik dan tari.

\section{Faktor Performer Apperance}

Dalam panggung kemampuan performer sangat diperlukan dalam pertunjukan, memiliki kreativitas, aksi dan penampilan atau kostum yang digunakan dalam pertunjukannya.

\section{Faktor Sound}

Pertunjukan seni baik musik, drama dan tari tidak terlepas dari teknologi yang digunakan seperti soundsystem dan kenyamanan saat menikmati suara atau bunyi yang dimainkan oleh pelaku seni.

\section{Stage Apperance}

Setting panggung pertunjukan yang menarik, baik dekorasi, latar, pencahayaan yang digunakan, menyangkut apa yang dilihat penonton saat menyaksikan pertunjukan.

\section{Facilities}

Fasilitas berupa kebutuhan penonton di mana dalam pertunjukan membutuhkan waktu yang cukup lama saat menyaksikannya, penonton dengan mudah menemukan fasilitas snack dan soft drink, toilet, parkir kendaraan dan menyangkut kenyamanan di tempat pertunjukan.

\section{Audience Interaction}

Antusias penonton merupakan salah satu interaksi yang dilakukan performer dan audience, dimana ada rasa keakraban dalam konser tersebut misalnya dalam musik popularitas lagu, sedangkan dalam pertunjukan tari, drama popularitas cerita/tokoh yang diangkat oleh penyaji.

\section{B. Kualitas Pelayanan}

Kualitas merupakan kondisi yang berpengaruh terhadap produk, jasa, manusia, proses, dan lingkungan yang memenuhi melebihi harapan konsumen. Kualitas pelayanan dapat diartikan sebagai upaya pemenuhan kebutuhan dan keinginan konsumen serta ketepatan penyampaian dalam mengimbangi harapan konsumen. Menurut Parasuraman, Zeithaml, Berry, (1988), terdapat lima dimensi SERVQUAL sebagai berikut:

1) Tangibles, fasilitas fisik, peralatan dan penampilan personel. Kualitas pelayanan berupa ruang tunggu, teknologi yang digunakan dalam panggung, kerapian petugas, dan fasilitas alat penunjang (pamflet, booklet)

2) Reliability, kemampuan untuk melakukan layanan yang dijanjikan dan akurat. Kemampuan petugas menyediakan layanan informasi jadwal pertunjukan dan proses reservasi tiket.

3) Responsiveness, kesediaan untuk membantu pelanggan dan memberikan layanan yang cepat. Kesanggupan untuk bersedia memberi bantuan kepada konsumen, membantu mencari deretan kursi sesuai tiket dan petugas yang selalu ada saat dibutuhkan.

4) Assurance, termasuk jaminan, kompetensi, kesopanan, kredibilitas dan keamanan. Pengetahuan dan kesopanan karyawan dan kemampuan mereka untuk menginspirasi 
kepercayaan dan keyakinan serta kemampuan mereka untuk menjawab pertanyaan konsumen. Dimensi kepastian atau jaminan ini merupakan gabungan dari dimensi:

a) kompetensi (competence), artinya keterampilan dan pengetahuan yang dimiliki oleh para karyawan untuk melakukan pelayanan;

b) kesopanan (courtesy), yang meliputi keramahan, perhatian, dan sikap para karyawan;

c) kredibilitas (credibility), meliputi hal-hal yang berhubungan dengan kepercayaan kepada perusahaan, seperti reputasi, prestasi dan sebagainya.

5) Empathy, termasuk akses, komunikasi, memahami pelanggan, perhatian-perhatian individual perusahaan kepada pelanggannya, dan memahami kebutuhan dari pelanggannya. Dimensi emphaty ini merupakan penggabungan dari tiga dimensi, yaitu sebagai berikut:

a) akses (access), meliputi kemudahan untuk memanfaatkan jasa yang ditawarkan perusahaan;

b) komunikasi (communication), merupakan kemampuan melakukan komunikasi untuk menyampaikan informasi kepada pelanggan atau cara memperoleh masukan dari pelanggan;

c) pemahaman pada pelanggan (understanding the consumer), meliputi usaha perusahaan untuk mengetahui dan memahami kebutuhan dan keinginan pelanggan.

\section{Persepsi Harga}

Swastha (2010: 147) menjelaskan bahwa harga adalah jumlah uang yang dibutuhkan untuk mendapatkan sejumlah kombinasi dari barang beserta pelayanannya. Selain harga dapat dilihat dari kesesuaian antara pengorbanan terhadap nilai yang dikorbankan, setelah melakukan pembelian dari situlah konsumen mempersepsikan produk atau jasa tersebut. Menurut Tjiptono, Chandra dan Adriana (2008) dalam Sabrina (2016) terdapat tiga indikator yaitu:

1. Kesesuaian harga dengan kualitas produk.

Presepsi yang dirasakan oleh konsumen dimana saat membeli sebuah produk merasakan ada kesesuaian dengan kualitas yang didapatkan, sehingga produk/jasa yang dibeli mampu diharapkan sesuai dengan harga yang didapat.

2. Kesesuaian harga dengan manfaat.

Pelanggan membeli sebuah produk atau jasa dengan harapan memiliki manfaat yang baik saat membeli sebuah produk/jasa tersebut, sehingga dirasa tidak menyesal untuk mengeluarkan uang dengan kata lain ada uang ada harga,ada harga ada manfaat.

3. Harga bersaing.

Harga menjadi komponen yang penting saat memilih untuk membeli salah satu produk, semakin murah semakin banyak yang membeli, semakin mahal sedikit yang membeli, namun tidak banyak juga yang percaya bahwa harga yang tinggi dengan kualitas yang memuaskan sehingga dengan nilai harga yang tinggi sesuai dengan kualitas di kelasnya.

\section{Kepuasan Penonton}

Kepuasan konsumen menjadi tujuan bagi perusahaan, dalam persaingan yang semakin meningkat membuat perusahaan harus memiliki strategi dalam bersaing baik dalam bertahan 
hidup dan berkembang sebab rasa puas dan tidak puas itu dirasakan oleh konsumen dan perusahaan diharuskan memenuhi harapan yang diinginkan bahkan melampaui harapan konsumen.

Menurut Oliver (1980:463) Ada empat item ukuran kepuasan untuk penelitian, semua item bersifat emosional (Hunt, 1977) langsung termasuk referensi kepada responden yaitu: kepuasan, penyesalan, kebahagiaan, dan perasaan umum tentang keputusan untuk menerima atau tidak menerima.

\section{Metodologi Penelitian}

\section{Lokasi Penelitian}

Lokasi penelitian ini dilakukan di Pertunjukan Sendratari Ramayana Prambanan, Jalan Raya Solo kilometer 16 Prambanan, Sleman, Yogyakarta.

\section{Metode Penelitian}

Pendekatan yang digunakan dalam penelitian ini adalah kuantitatif untuk menggambarkan pengaruh antarvariabel secara statistik dan dideskripsikan untuk memperoleh fakta-fakta data yang diprediksi dengan hasil data yang nanti bisa dievaluasi bagi pihak pengelola pertunjukan. Metode penelitian menggunakan cross sectional (potong lintang) yaitu rancangan penelitian dengan melakukan pengukuran atau pengamatan pada saat bersaman atau sekali waktu (Hidayat, 2007).

\section{Teknik Pengumpulan Data}

Adapun jenis penelitian ini menggunakan metode survei, bentuk teknik penelitian ini berupa informasi yang dikumpulkan dari responden, melalui instrumen berupa pertanyaanpertanyaan (kuesioner).

Populasi dan sampel dalam penelitian ini adalah semua penonton pertunjukan di panggung terbuka dan panggung tertutup Sendratari Ramayana Prambanan. Dalam menentukan sampel responden yang digunakan adalah accidental sampling ini dilakukan dengan mengambil responden yang kebetulan tersedia di suatu tempat.

\section{Teknik Analisis Data}

\section{Uji Validitas dan Reliabilitas}

Uji validitas sering digunakan untuk mengukur ketepatan suatu item dalam kuisioner, apakah item pada kuisioner tersebut sudah tepat dalam mengukur apa yang ingin diukur. Hasil kuesioner yang telah diisi kemudian diolah menggunakan rumus korelasi product moment dengan signifikansi sebesar $>0,05$ melalui bantuan program komputer. Rumus korelasi product moment yaitu: 


$$
\mathbf{r}_{\mathbf{x y}}=\frac{\mathrm{N} \Sigma x y-(\Sigma x)(\Sigma y)}{\sqrt{\left[N \Sigma x^{2}-\left(\Sigma x^{2}\right)\right]\left[N \Sigma y^{2}-\left(\Sigma y^{2}\right)\right]}}
$$

\section{Keterangan:}

$$
\begin{array}{ll}
\text { Rxy } & : \text { Indeks korelasi antara item } \mathrm{x} \text { dengan } \mathrm{y} \\
\mathrm{N} & : \text { Banyaknya responden } \\
\mathrm{X} & : \text { Skor yang diperoleh subyek dari seluruh item } \\
\mathrm{Y} & : \text { Skor total yang diperoleh dari seluruh item } \\
N \sum \mathrm{x} & : \text { Jumlah skor dalam distribusi } \mathrm{X} \\
\sum \mathrm{y} & : \text { Jumlah skor dalam distribusi } \mathrm{Y}
\end{array}
$$

Uji reliabilitas berguna untuk menetapkan apakah instrumen, dalam hal ini kuesioner, dapat digunakan lebih dari satu kali, paling tidak oleh responden yang sama. Uji reliabilitas untuk alternatif jawaban lebih dari dua menggunakan uji Cronbach's Alpha dengan signifikansi, yang nilainya akan dibandingkan dengan nilai koefisien reliabilitas minimal yang dapat diterima. Rumus Alpha Cronbach yaitu:

$$
\mathrm{r}_{11}=\left(\frac{k}{(k-1)}\right)\left(1-\frac{\sum \sigma_{b}^{2}}{\sigma_{t}^{2}}\right)
$$

\section{Keterangan:}

$$
\begin{aligned}
\mathrm{r}_{11} & : \text { Reliabilitas instrumen } \\
\mathrm{k} & : \text { Banyaknya butir pertanyaan atau banyaknya soal } \\
\sum \sigma_{b} 2 & : \text { Jumlah varians butir } \\
\sigma^{2} t & : \text { Varians total. }
\end{aligned}
$$

\section{Skala Pengukuran}

Dalam penelitian ini menggunakan skala Likert. Skala digunakan untuk mengukur variabel independen dan dependen terhadap kondisi yang dirasakan responden terhadap objek yang diamati sesuai dengen kuesioner yang diberikan.

Skala Likert memiliki lima bobot penilaian digunakan dengan lima tingkatan yang diberi skor sebagai berikut, Sugiyono (2013):
a. Sangat setuju diberi skor lima
$=5$
b. Setuju diberi skor empat
$=4$
c. Netral diberi skor tiga
$=3$
d. Tidak setuju diberi skor dua
$=2$
e. Sangat tidak setuju diberi skor satu $=1$ 
Pembobotan untuk pernyataan negatif (-) digunakan lima tingkatan yang diberi skor sebagai berikut:

a. Sangat setuju diberi skor satu $\quad=1$

b. Setuju diberi skor dua $=2$

c. Netral diberi skor tiga $=3$

d. Tidak setuju diberi skor empat $\quad=4$

e. Sangat tidak setuju diberi skor lima $=5$

Analisis Regresi Linier Berganda

Ghozali (2011: 96) menjelaskan bahwa analisis regresi berganda adalah alat analisis peramalan nilai pengaruh dua variabel bebas atau lebih terhadap variabel terikat untuk membuktikan ada tidaknya hubungan fungsi atau kausal antara dua variabel bebas atau lebih dan satu variabel terikat. Dalam penelitian ini menggunakan regresi berganda digunakan untuk mengetahui kelinieran pengaruh kualitas pelayanan, live performance, persepsi harga terhadap kepuasan penonton.

Selain mengukur kekuatan hubungan dua variabel atau lebih, juga menunjukkan arah hubungan antara variabel dependen dan independen. Adapun rumus regresi linier berganda sebagai berikut:

$\mathrm{Y}=\mathrm{bo}++\mathrm{b} 1 . \mathbf{X 1}+\mathbf{b 2 . X 2}+\mathbf{b 3 . X 3} \mathrm{e}$

Keterangan:

$\mathrm{Y}=$ Kepuasan Penonton

Bo $=$ Konstanta

$\mathrm{X} 1$ = Variabel Kualitas Pelayanan

$\mathrm{X} 2$ = Variabel Live Performance

X3 = Variabel Persepsi Harga

$\mathrm{e}=$ Error Term

\section{Uji Hipotesis}

Uji F

Ghozali (2013:17), menjelaskan bahwa uji t digunakan untuk mengetahui seberapa jauh pengaruh satu variabel independen terhadap variabel dependen. Hasil uji ini pada output SPSS dapat dilihat dari tabel Coefficience ${ }^{b}$. Nilai uji t dilihat dari $p$-value terdapat pada kolom signifikan tiap variabel independen.

\section{Uji T}

Ghozali (2013:16) menjelaskan bahwa Uji F digunakan untuk mengetahui apakah variabelvariabel independen secara simultan berpengaruh terhadap variabel dependen. Hasil uji F ini hasil dari output dari SPSS dari $A N O V A^{b}$. 
Kofiesien Determinasi $\left(\mathrm{R}^{2}\right)$

Ghozali (2011), koefisien determinasi $\left(\mathrm{R}^{2}\right)$ digunakan untuk mengetahui persentase sumbangan pengaruh variabel indepanden terhadap variabel dependen. Pada initinya mengukur seberapa jauh kemampuan model dalam menerangkan variasi variabel dependen.

Kriteria Keputusan

Hipotesis :

$\mathrm{Ho}=$ Tidak ada pengaruh Live Performance, Kualitas Pelayanan, dan Persepsi Harga terhadap Kepuasan Penonton Sendaratari Ramayana Prambanan.

$\mathrm{Ha} \neq$ Ada pengaruh Live Performance, Kualitas Pelayanan, dan Persepsi Harga terhadap Kepuasan Penonton Sendaratari Ramayana Prambanan.

Signifikansi :

Dengan membandingkan $F_{\text {hitung }}$ dengan $F_{\text {tabel, }}$, apabila $F_{\text {hitung }}>F_{\text {tabel}}$, maka Ho ditolak dan Ha diterima. Apabila $\mathrm{F}_{\text {hitung }}<\mathrm{F}_{\text {tabel, }}$ maka Ho diterima dan Ha ditolak. Dengan angka signifikansi jika probabilitas $>0,05$ maka Ho ditolak dan Ha diterima. Jika probabilitas $<0,05$ maka Ho diterima dan Ha ditolak.

\section{Uji Beda (Independent Samples Test)}

Uji beda dilakukan untuk mengetahui apakah dua sampel yang tidak berhubungan memiliki nilai rata-rata yang berbeda. Uji beda t-test dilakukan dengan cara membandingkan perbedaan antara dua nilai rata-rata dengan cara membandingkan perbedaan antara dua nilai rata-rata dengan standar error dari perbedaan rata-rata dua sampel atau secara rumus dapat ditulis sebagai berikut (Ghozali, 64: 2011):

$$
\mathrm{t}=\frac{\text { Rata-rata sampel pertama }- \text { Rata-rata sampel kedua }}{\text { standar error perbedaan rata-rata kedua sampel }}
$$

Uji beda terdapat dua cara yaitu statistik parametik (independen) dan nonparametik (mann whitney), Ada beberapa syarat yang diperlukan untuk uji beda sampel T-Test yaitu:

1. Data kuantitatif harus diuji normalitas, hasilnya harus berdistribusi normal dan data harus sejenis atau homogen untuk uji beda independen.

2. Data tidak berdistribusi normal dan tidak homogen harus menggunakan statistik nonparametik yaitu uji Mann Whitney. 


\section{Hasil Dan Pembahasan}

\section{A. Validitas dan Reliabilitas}

Tabel 1. Hasil Uji Validitas dan Reliabilitas

\begin{tabular}{|c|c|c|c|}
\hline Dimensi & Item Indikator & $\begin{array}{l}\text { Corected Item-Total } \\
\text { Correlation }(r)\end{array}$ & $\begin{array}{l}\text { Cronbach } \\
\text { Alpha }(\alpha)\end{array}$ \\
\hline \multirow{22}{*}{ Kualitas Pelayanan } & KP1 & .613 & \multirow{22}{*}{.917} \\
\hline & KP2 & .602 & \\
\hline & KP3 & .579 & \\
\hline & KP4 & .556 & \\
\hline & KP5 & .770 & \\
\hline & KP6 & .517 & \\
\hline & KP7 & .601 & \\
\hline & KP8 & .723 & \\
\hline & KP9 & .587 & \\
\hline & KP17 & .585 & \\
\hline & KP14 & .589 & \\
\hline & KP15 & .579 & \\
\hline & KP16 & .617 & \\
\hline & KP13 & .609 & \\
\hline & KP12 & .727 & \\
\hline & KP11 & .647 & \\
\hline & KP10 & .535 & \\
\hline & KP18 & .621 & \\
\hline & KP19 & .568 & \\
\hline & KP20 & .571 & \\
\hline & KP21 & .634 & \\
\hline & KP22 & .547 & \\
\hline \multirow{13}{*}{ Live Performance } & LP1 & .571 & \multirow{13}{*}{.876} \\
\hline & LP2 & .563 & \\
\hline & LP3 & .800 & \\
\hline & LP4 & .626 & \\
\hline & LP5 & .588 & \\
\hline & LP6 & .634 & \\
\hline & LP7 & .623 & \\
\hline & LP8 & .764 & \\
\hline & LP9 & .614 & \\
\hline & LP10 & .643 & \\
\hline & LP11 & .687 & \\
\hline & LP12 & .562 & \\
\hline & LP13 & .676 & \\
\hline \multirow[b]{2}{*}{ Persepsi Harga } & PH1 & .805 & \\
\hline & $\mathrm{PH} 2$ & .896 & \\
\hline
\end{tabular}




\begin{tabular}{|c|c|c|c|}
\hline & PH3 & .765 & \multirow[t]{2}{*}{.835} \\
\hline & PH4 & .804 & \\
\hline \multirow{6}{*}{ Kepuasan Penonton } & KPN1 & .648 & \multirow{6}{*}{.913} \\
\hline & KPN2 & .662 & \\
\hline & KPN3 & .843 & \\
\hline & KPN4 & .936 & \\
\hline & KPN5 & .939 & \\
\hline & KPN6 & .948 & \\
\hline
\end{tabular}

*VALID dan RELIABEL

\section{B. Profil Demografi Responden}

Hasil rekapitulasi 100 kuesioner ditemukan berbagai profil demografi responden yang berkontribusi dan berpartisipasi yang mengisi kuesioner dan penilaian terhadap pengaruh live performance, kualitas pelayanan dan persepsi harga terhadap kepuasan penonton sendratari Ramayana Prambanan.

Tabel 2 Profil Demografi Responden Panggung Tertutup dan Terbuka

\begin{tabular}{|c|c|c|c|c|c|}
\hline \multirow[t]{2}{*}{ Demografi } & \multirow[t]{2}{*}{ Keterangan } & \multicolumn{2}{|l|}{ Jumlah } & \multicolumn{2}{|l|}{ Persentase } \\
\hline & & $\begin{array}{l}\text { Panggung } \\
\text { Tertutup }\end{array}$ & $\begin{array}{l}\text { Panggung } \\
\text { Terbuka }\end{array}$ & $\begin{array}{l}\text { Panggung } \\
\text { Tertutup }\end{array}$ & $\begin{array}{l}\text { Panggung } \\
\text { Terbuka }\end{array}$ \\
\hline \multirow{2}{*}{$\begin{array}{l}\text { Jenis } \\
\text { Kelamin }\end{array}$} & Laki-laki & 40 & 52 & $40 \%$ & $52 \%$ \\
\hline & Perempuan & 60 & 48 & $60 \%$ & $48 \%$ \\
\hline \multirow{5}{*}{ Usia } & Usia $<20$ tahun & - & & - & - \\
\hline & Usia 20-29 tahun & 41 & 44 & $41 \%$ & $44 \%$ \\
\hline & Usia 30-39 tahun & 21 & 29 & $21 \%$ & $29 \%$ \\
\hline & Usia 40-49 tahun & 20 & 18 & $20 \%$ & $18 \%$ \\
\hline & Usia 50 tahun & 18 & 9 & $18 \%$ & $9 \%$ \\
\hline \multirow{7}{*}{$\begin{array}{l}\text { Pendidikan } \\
\text { Terakhir }\end{array}$} & $\mathrm{SD}$ & - & & - & - \\
\hline & SMP & - & & - & - \\
\hline & SMA & - & & - & - \\
\hline & Diploma & 29 & 19 & $29 \%$ & $19 \%$ \\
\hline & Sarjana & 47 & 65 & $47 \%$ & $65 \%$ \\
\hline & Strata-2 & 22 & 12 & $22 \%$ & $12 \%$ \\
\hline & Strata-3 & 2 & 4 & $2 \%$ & $4 \%$ \\
\hline
\end{tabular}

\section{Sumber: data diolah, 2017}

Berdasarkan distribusi frekuensi pada tabel 2, secara garis besar mayoritas karakteristik demografi kategori jenis kelamin pada panggung tertutup oleh perempuan dengan persentase $60 \%$. Artinya mayoritas penonton pada panggung tertutup berjenis kelamin perempuan. Adapun karakteristik demografi kategori jenis kelamin pada panggung terbuka mayoritas berjenis kelamin laki-laki dengan persentase $52 \%$. 
Adapun persentase berdasarkan usia pada panggung tertutup pada usia 20-29 tahun sebanyak $41 \%$ dan pada panggung terbuka berdasarkan usia juga mayoritas usia 20-29 tahun sebesar $44 \%$ dengan pendidikan terakhir panggung tertutup yang didominasi lulusan sarjana $47 \%$ dan pada panggung terbuka didominasi sarjana sebesar $65 \%$ yang terlibat dalam penelitian ini.

Analisis Regresi Berganda Pervariabel Panggung Tertutup

\begin{tabular}{|c|c|c|c|c|}
\hline \multicolumn{2}{|l|}{ Variabel } & Koefisien & $\mathbf{t}$ & Sig. \\
\hline \multicolumn{2}{|c|}{$\begin{array}{l}\text { Live Performance } \\
\text { (X1) }\end{array}$} & .179 & 3.481 & .001 \\
\hline \multicolumn{2}{|c|}{$\begin{array}{l}\text { Kualitas Pelayanan } \\
\text { (X2) }\end{array}$} & .072 & 2.828 & .006 \\
\hline \multicolumn{2}{|c|}{$\begin{array}{l}\text { Persepsi Harga } \\
\text { (X3) }\end{array}$} & .402 & 2.934 & .004 \\
\hline Konstanta & 2.394 & & & \\
\hline $\mathrm{F}_{\text {hitung }}$ & 23.136 & & & \\
\hline Sig. F & .000 & & & \\
\hline Adj. R & .401 & & & \\
\hline
\end{tabular}

*Nilai signifikan $<5 \%$

Sumber: data diolah, 2017

\section{Pembahasan Pengaruh Live Performance, Kualitas Pelayanan, Persepsi Harga terhadap Kepuasan Penonton Sendratari Ramayana Prambanan (Panggung Tertutup)}

Tujuan mendasar dari penelitian ini yaitu untuk mengetahui pengaruh live performance, kualitas pelayanan, persepsi harga terhadap kepuasan penonton Sendratari Ramayana Prambanan pada panggung tertutup yang tidak terlepas dari profil demografi dan pengaruh terhadap berbagai perilaku untuk mencari kepuasan.

Data demografi pada penelitian ini menemukan bahwa wanita gemar menonton pertunjukan tari daripada laki-laki karena sifat feminimisme sebuah tarian membuat wanita lebih tertarik dari pada laki-laki yang memandang negatif tarian tidak bersifat gagah dan maskulin.

Hasil penelitian secara statistik menunjukan nilai $F_{\text {hitung }}$ sebesar 23.136 dengan signifikansi $\mathrm{F}=0,000<0,05$, dengan model regresi signifikan secara statistik dengan kata lain bahwa variabel X1, X2, dan X3 berpengaruh terhadap kepuasan penonton (Y) Sendratari Ramayana Prambanan. Nilai $\mathrm{R}$ squares $\left(\mathrm{R}^{2}\right)$ sebesar 0,401 , nilai tersebut menunjukkan bahwa $40,1 \%$ varians yang terjadi terhadap kepuasan penonton yang dapat dijelaskan melalui varians yang terdapat pada variabel X1, X2, dan X3 sebesar 59,9\% yang ditentukan oleh faktor lain.

Variabel paling dominan mempengaruhi kepuasan penonton Sendratari Ramayana Prambanan adalah variabel live performance (X1) dengan nilai signifikan 0,001. Pertama, variabel live performance yang dominan mempengaruhi kepuasan penonton pada panggung tertutup karena penyajian oleh pemain mampu menjawab keinginan yang dirasakan oleh 
penonton dengan harapan-harapan yang sesuai saat datang untuk menyaksikan pertunjukan, adanya keberadaan fasilitas seperti cemilan dan minuman, cerita yang populer, dekorasi yang sesuai, tata suara yang baik, dan maksimalnya penari dalam mementaskan pertunjukan menjadi hal yang menjawab harapan penonton saat menyaksikan pertunjukan sehingga pilihan penonton saat berkeputusan membeli tiket adalah pilihan yang tepat.

Kedua, variabel persepsi harga mempengaruhi kepuasan penonton dikarenakan sebagian penonton merasa manfaat yang diberikan lebih baik daripada harganya, serta harga yang ditawarkan untuk pertunjukan Sendratari Ramayana Prambanan pada panggung tertutup bisa bersaing di kelasnya dan cukup terjangkau di kalangan penikmat seni dan budaya.

Ketiga, variabel kualitas pelayanan mempengaruhi kepuasan penonton dikarenakan pelayanan yang diberikan cukup baik hanya saja ada beberapa pelayanan disabilitas yang kurang memadai, dimana pada pelayanan penyandang disabilitas dan aksesbilitas kurang memenuhi harapan penonton untuk menyaksikan pertunjukan Sendratari Ramayana Prambanan

\section{Analisis Regresi Berganda Per-variabel Panggung Terbuka}

\begin{tabular}{|c|c|c|c|c|}
\hline \multicolumn{2}{|l|}{ Variabel } & Koefisien & $\mathbf{t}$ & Sig. \\
\hline \multicolumn{2}{|c|}{ Live Performance (X1) } & .119 & 2.116 & .037 \\
\hline \multicolumn{2}{|c|}{ Kualitas Pelayanan (X2) } & .126 & 3.309 & .001 \\
\hline \multicolumn{2}{|c|}{ Persepsi Harga (X3) } & .423 & 2.145 & .034 \\
\hline Konstanta & -.858 & & & \\
\hline $\mathrm{F}_{\text {hitung }}$ & 14.400 & & & \\
\hline Sig. F & .000 & & & \\
\hline R Square & .289 & & & \\
\hline
\end{tabular}

Sumber: data diolah, 2017

\section{Pembahasan Pengaruh Live Performance, Kualitas Pelayanan, Persepsi Harga terhadap Kepuasan Penonton Sendratari Ramayana Prambanan (Panggung Terbuka)}

Profil responden pada panggung terbuka dalam jenis kelamin responden ini menemukan bahwa laki-laki lebih tertarik menonton pertunjukan tari daripada panggung terbuka, pada panggung terbuka karena didominasi oleh kelompok kesenian berjenis kelamin laki-laki saat menonton pertunjukan Sendratari Ramayana Prambanan, disisi lain faktor keluarga diduga akibat aktivitas pertunjukan di malam hari.

Hasil penelitian menunjukan nilai $\mathrm{F}_{\text {hitung }}$ sebesar 14.400 dengan signifikansi $\mathrm{F}=0,000^{\mathrm{a}}$ $<0,05$, dengan model regresi signifikan secara statistik dengan kata lain bahwa variabel live performance, kualitas pelayanan, persepsi harga, berpengaruh terhadap kepuasan penonton (Y) Sendratari Ramayana Prambanan. Nilai R squares (R2) sebesar 0,289, nilai tersebut menunjukkan bahwa $28,9 \%$ varians yang terjadi terhadap kepuasan penonton yang dapat 
dijelaskan melalui varians yang terdapat pada variabel live performance, kualitas pelayanan, persepsi harga, berpengaruh terhadap kepuasan penonton (Y), sebesar 71,1\% yang ditentukan oleh faktor lain.

Faktor pertama, variabel kualitas pelayanan pada panggung terbuka dalam segi pelayanannya pada panggung terbuka lebih baik, adanya fasilitas yang memadai seperti snack dan minuman, toilet, dan fasilitas umum lainnya, pelayanan yang diberikan kepada penyandang disabilitas pada panggung terbuka lebih baik dikarenakan adanya jalur khusus dan tempat khusus penonton penyandang disabilitas yang memadai. Kerapian dan cepat tanggapnya pelayan menjadi hal yang penting pada panggung terbuka dimana petugas sigap saat memenuhi keluhan penonton. Dengan demikian kualitas pelayanan mempunyai dampak langsung pada pelayanan dan jasa. Oleh karena itu, kualitas berhubungan erat dengan nilai dan kepuasan pelanggan pada panggung terbuka.

Faktor kedua yang mempengaruhi kepuasan konsumen adalah harga. Jika harga tidak sesuai dengan manfaat produk/jasa hal tersebut dapat menurunkan tingkat kepuasan konsumen, dan sebaliknya jika harga yang ditetapkan sesuai dengan manfaat yang diterima maka akan meningkatkan kepuasan pelanggan. Pada tingkat harga tertentu, jika manfaat yang dirasakan meningkat, maka nilainya akan meningkat pula. Demikian juga dengan pertunjukan Sendratari Ramayana Prambanan, semakin nilai yang dirasakan penonton jauh lebih bermanfaat maka, harga tidak menjadi hal yang begitu membebankan bagi pelanggan, semakin besar manfaat itu semahal apapun penonton akan tetap ingin menyaksikan pertunjukan tersebut dengan cara meningkatkan kualitas pelayanan dan pertunjukannya.

Faktor ketiga tentang live performance, sebaliknya mengalami perbedaan dimana kurang maksimalnya penari dan totalitas dalam berperan masih terlihat kurang totalitas, sebagaimana keterkaitannya dengan kepuasan variabel live performance juga menjadi pengaruh bagi kepuasan penonton, berkaitan dengan harga, penonton memiliki ekspektasi ketika membeli tiket pertunjukan Sendratari Ramayana Prambanan adanya harapan-harapan untuk menjumpai pengalaman yang menarik dan tidak terlupakan, sehingga pertunjukan yang terlihat maksimal membuat penonton untuk ingin kembali menyaksikan pertunjukan episode Sendratari Ramayana Prambanan tersebut tanpa melihat harganya namun nilai, manfaat, dan totalitas penari, menjadi keinginan penonton untuk kembali menyaksikan pertunjukan Sendratari Ramayana Prambanan.

\section{E. Hasil Uji Beda Panggung Terbuka dan Tertutup}

Tabel 3 Hasil Uji Beda

\begin{tabular}{|c|c|c|c|c|}
\hline Variabel & Lokasi & Mean & Sig. & Keterangan \\
\hline \multirow[t]{2}{*}{ Live Performance (X1) } & Tutup & 54.3200 & \multirow[b]{2}{*}{.513} & \multirow[t]{2}{*}{ Tidak signifikan } \\
\hline & Buka & 53.7100 & & \\
\hline \multirow[t]{2}{*}{ Kualitas Pelayanan (X2) } & Tutup & 90.5000 & \multirow[b]{2}{*}{.960} & \multirow{2}{*}{$\begin{array}{l}\text { Tidak } \\
\text { signifikan }\end{array}$} \\
\hline & Buka & 90.5800 & & \\
\hline \multirow[t]{2}{*}{ Persepsi Harga (X3) } & Tutup & 16.4700 & \multirow[b]{2}{*}{.868} & \multirow{2}{*}{$\begin{array}{l}\text { Tidak } \\
\text { signifikan }\end{array}$} \\
\hline & Buka & 16.5200 & & \\
\hline \multirow[t]{2}{*}{ Kepuasan Penonton (Y) } & Tutup & 23.9500 & \multirow[b]{2}{*}{.025} & \multirow{2}{*}{$\begin{array}{l}\text { Signifikan } \\
\text { (Ada perbedaan) }\end{array}$} \\
\hline & Buka & 25.1700 & & \\
\hline
\end{tabular}




\section{F. Pembahasan Uji Independen pada Panggung Terbuka dan Panggung Tertutup Ramayana Prambanan.}

Hasil pengujian independent sample t-test menunjukkan nilai mean pada panggung tertutup sebesar 23.9500 dan panggung terbuka 25.1700 dengan nilai selisih yang sama pada panggung tertutup dan panggung terbuka. $\mathrm{T}_{\text {hitung }}-2.256$ memiliki kesamaan dengan signifikan sebesar 0,025 kurang dari 5\% $(0,025<0,05)$. Dengan demikian dapat disimpulkan bahwa pengaruh live performance, kualitas pelayanan, dan persepsi harga terhadap kepuasan penonton Sendratari Ramayana Prambanan pada panggung tertutup dan terbuka memiliki perbedaan.

Panggung terbuka memiliki nilai selisih lebih besar dari pada panggung tertutup dikarenakan adanya perasaan yang puas dalam mengambil keputusan untuk menyaksikan pertunjukan pada panggung terbuka. Menurut Tjiptono (2008:50), konsumen yang puas akan membeli dan mencoba lagi tetapi jika sebaliknya kemungkinan akan melakukan komplain. Perasaan senang dan puas menjadi harapan pada setiap usaha yang berkembang baik dalam bidang produksi dan jasa yang ditawarkan, perlunya konsistensi dalam pelayanan yang berkualitas, petugas yang profesional, dan harga yang terjangkau tetapi mampu bersaing di kelasnya.

Panggung tertutup ada beberapa faktor yang mempengaruhi dari segi pelayanannya, kurangnya fasilitas yang memudahkan penonton untuk merasa nyaman, kapasitas gedung yang kecil namun penonton banyak hadir untuk menonton, beberapa kekurangan yang membuat panggung tertutup kurang puas, seperti fasilitas penyandang disabilitas yang tidak memiliki ruang sendiri seperti pada panggung terbuka. Undang-undang Republik Indonesia Nomor 8 Tahun 2016 tentang penyandang disabilitas adalah setiap orang yang mengalami keterbatasan fisik, intelektual, mental dan/atau sensorik dalam jangka waktu lama yang dalam berinteraksi dengan lingkungan dapat mengalami hambatan dan kesulitan untuk berpartisipasi secara penuh dan efektif dengan warga negara lainnya berdasarkan kesamaan hak.

\section{Kesimpulan}

Berdasarkan hasil analisis pengujian independent sample t-test menunjukan nilai mean pada panggung tertutup sebesar 23.9500 dan panggung terbuka 25.1700 dengan nilai selisih yang sama pada panggung tertutup dan panggung terbuka. $\mathrm{T}_{\text {hitung }}-2.256$ memiliki kesamaan dengan signifikan sebesar 0,025 kurang dari $5 \%(0,025<0,05)$. Pengaruh live performance, kualitas pelayanan dan persepsi harga terhadap kepuasan penonton sendratari Ramayana Prambanan pada panggung tertutup dan terbuka terdapat perbedaan yang signifikan, penonton lebih merasa puas pada panggung terbuka dari pada pangung tertutup.

\section{Saran}

Berdasarkan hasil penelitian yang telah dilakukan, pembahasan dan kesimpulan yang diperoleh, maka saran yang diberikan yaitu sebagai berikut.

1. Saran Implikasi bagi Pengelola Ramayana Prambanan 
Mengacu pada item pertanyaan variabel kualitas pelayanan dengan skor terendah sebaiknya pengelola Sendratari Ramayana Prambanan pada panggung tertutup lebih meningkatkan pelayanan yang diberikan tidak hanya pada penonton yang sehat jasmani dan rohani namun juga pada penyandang disabilitas dan kepadatan penonton yang membuat penonton menyaksikan pertunjukan berdiri karena kekurangan fasilitas tempat duduk untuk penonton. Pada variabel live performance pada panggung terbuka sendiri memiliki skor terendah. Hal ini khususnya berkaitan dengan totalitas pemain pada episode "Gugurnya Kumbakarna" dalam menyajikan penampilan. Untuk perbedaan panggung tertutup dan panggung terbuka Ramayana Prambanan, terdapat perbedaan kepuasan yaitu penonton lebih puas menyaksikan pertunjukan Sendratari Ramayana Prambanan pada panggung terbuka dari pada panggung tertutup.

2. Saran Implikasi bagi Penelitian Selanjutnya

Diharapkan untuk peneliti selanjutnya dapat mengkaji lebih dalam tentang live performance, kualitas pelayanan dan persepsi harga yang berpengaruh terhadap kepuasan penonton agar diperoleh gambaran yang lebih lengkap lagi, sehingga diharapkan hasil penelitian yang akan datang lebih baik dari penelitian ini. Peneliti selanjutnya dapat mengembangkan penelitian ini dengan mencari faktor lain yang dapat mempengaruhi live performance, kualitas pelayanan, dan persepsi harga terhadap kepuasan penonton Sendratari Ramayana Prambanan.

Mengingat besarnya ketiga variabel bebas tersebut hanya berpengaruh nilai $\mathrm{R}$ squares $\left(\mathrm{R}^{2}\right)$ sebesar 0,401 , nilai tersebut menunjukkan bahwa 40,1\% varians yang terjadi terhadap kepuasan penonton yang dapat dijelaskan melalui varians yang terdapat pada variabel live performance, kualitas pelayanan, dan persepsi harga pada panggung tertutup sebesar 59,9\% yang ditentukan oleh faktor lain dan pada panggung terbuka nilai $\mathrm{R}$ squares $\left(\mathrm{R}^{2}\right)$ sebesar 0,289 , nilai tersebut menunjukkan bahwa $28,9 \%$ varians yang terjadi terhadap kepuasan penonton yang dapat dijelaskan melalui varians yang terdapat pada variabel live performance, kualitas pelayanan, persepsi harga berpengaruh terhadap kepuasan penonton, sebesar $71,1 \%$ yang ditentukan oleh faktor lain.

\section{Keterbatasan Penelitian}

1. Dalam penelitian ini, pengambilan data penelitian menggunakan menggunakan angket atau kuesioner sehingga kedalaman data masih kurang dalam menggali pengaruh live performance, kualitas pelayanan, dan persepsi harga terhadap kepuasan penonton Sendratari Ramayana Prambanan.

2. Penelitian ini menggunakan riset cross sectional, dimana rancangan penelitian ini dilakukan pengukuran dan pengamatan pada saat bersamaan atau sekali waktu. Pertunjukan Ramayana Prambanan digelar pada rentang bulan yang ditentukan oleh musim yang berhubungan dengan kondisi cuaca sehingga penelitian ini hanya bisa dilakukan sekali waktu.

3. Penelitian ini hanya meneliti pengaruh live performance, kualitas pelayanan, dan persepsi harga sebagai variabel independen dan kepuasan penonton sebagai variabel dependen. Masih ada faktor lain yang dapat mempengaruhi kepuasan penonton. Misalnya dengan metode kualitatif data diperoleh dari pendapat penonton dan melibatkan pengelola Ramayana Prambanan. Demikian juga dengan metode kuantitatif dapat menambah variabel untuk selanjutnya dikorelasikan dengan analisis yang lain. 


\section{Kepustakaan}

Minor A Tilman, W.F.J. Brewerton, Angela H. Rock on! An elementary model of consumer statisfication with musical performances. Journal of services marketing. Vol. 18 No. 1. Pp.7-18.2004.

Parasuraman, A. Zeithaml., Valerie, A., Berry, Leonard L. (1988). Servqual: A Mulitple-Item Scale for Measuring Consumer Perceptions of Service Quality. Journal of Retailing. Vol. 64 No.1. Hlm. 12-40.

Sabrina, Ridha 2016. tentang pengaruh kualitas pelayanan, harga dan lokasi terhadap keputusan pembelian tiket bioskop XXI Yogyakarta. Skripsi. Tidak dipublikasi

Oliver, R.L. (1980), "A cognitive model of the antecedents and consequences of satisfaction decisions”, Journal of Marketing Research, Vol. 17 No. 4, pp. 460-9.

Ghozali, Imam. 2013. Aplikasi Analisis Multivariate dengan Program SPSS. Cetakan VII. Semarang: Badan Penerbit Universitas Diponegoro Semarang.

Ghozali, Imam. 2011. Aplikasi Analisis Multivariate dengan Program IBM SPSS 19.Cetakan V. Semarang: Badan Penerbit Universitas Diponegoro Semarang. 